\title{
DON QUIJOTE NO ASCETA, PERO EJEMPLAR CABALLERO Y CRISTIANO
}

Mi querido colcga y distinguido colaborador Helmut Hatzfeld ha publicado en esta Nueva Revista de Filología Hispánica, II, págs. 57-70, un artículo que lleva por título una pregunta: ¿Don Quijote asceta?, a la que, con textos del Quijote cuidadosamente ordenados, se contesta negativamente. $Y$ aunque esa labor llena el artículo casi en su totalidad, no es más que prcliminar para comprobar "si don Quijote representa el ideal ascético de la Iglesia y la Contrarrcforma, o está contra él, con el Renacimiento italiano y la tendencia luterana de Erasmo y el erasmismo" (pág. 57). La respuesta se recoge en la pág. 69: "don Quijote resulta un paradigma de humanistas y alumbrados, los cuales coinciden en un punto de sus tendencias, por lo demás muy dispares: en que tratan de cambiar el ideal cristiano teocéntrico por un conocimiento o emoción antropocéntricos".

Yo me encuentro en completo acucrdo con Hatzfeld en que don Quijote no es asceta, y en que los ideales rcligiosos son incomparablemente superiores a los seculares. Pero me va a permitir mi querido colega que me muestre luego sorprendido e incrédulo de las alternativas que plantea: el que don Quijote no sea asceta no impone a mi razón que esté contra la Iglesia romana (¡Dios mío, excepto unos pocos, lo habrían estado todos los cspañoles de su tiempo!). También reconozco que cl ideal caballeresco tal como se formulaba y practicaba anacrónicamente en el Amadís y dcmás libros de caballerías, y el ideal del cortesano tal como se expone en cl libro de Castiglione y como se practicaba en toda Europa, eran, en efecto, seculares, y que ese ideal caballeresco y cortesano (enriquecido con ciertas esencias de la épica, como ha hecho ver Menéndez Pidal) es el que impera en la fantasía enferma de don Quijote. Y sin cmbargo, leyendo y releyendo el Quijote, considerando con todo cuidado y uno por uno los textos aducidos por Hatzfeld y otros que no aduce, no encuentro el menor indicio de que don Quijote esté contra la Iglesia, ni que trate de cambiar cl ideal cristiano por otro antropocéntrico que se desentienda de Dios. Sus desvaríos hieren a la razón, no a la religión. Alonso Quijana fué un buen cristiano del llano (no un San Pedro de Alcántara, claro), antes y después de su locura, y don Quijote siguió sicndo un buen cristiano durante su locura. Cierto que persigue y practica cxcclencias y virtudes (castidad, esfuerzo, servicio, templanza, justicia, heroísmo) cuya justificación su fantasía enferma pone en las reglas de caballería; pero jamás vive don Quijote esas virtudes como un sustituto de las cristianas, ni menos como una oposición ${ }^{1}$. Es al juego, a las reglas de juego de su mundo

1 Una vez parece don Quijote no sólo oponer su religión caballeresca a la cristiana, sino apreciar aquélla por encima de ésta: "Unos van por el ancho campo... de la verdadera religión; pero 
caballeresco a lo que su fantasía atiende, pero los cimientos de su conducta son firmemente cristianos. Su Dulcinea no suplanta a Dios; si se encomienda a ella, suele ser después de encomendarse a Dios, y por cumplir las reglas. El mismo don Quijote lo ha aclarado (I, 13):

- Señor - respondió don Quijote-, eso no puede ser menos en ninguna manera, y caería en mal caso el caballero andante que otra cosa hiciese; que ya está en uso y costumbre de la caballería andantesca que el caballero andante que al acometer algún gran fecho de armas tuviese su señora delante, vuelva a ella los ojos blanda y amorosamente como que le pide con ellos le favorezca y ampare en el dudoso trance que acomete; y aun si nadie le oye, está obligado a decir algunas palabras entre dientes, en que de todo corazón se le encomiende, y desto tenemos innumerables ejemplos en las historias. Y no se ha de entender por eso que han de dejar de encomendarse a Dios, que tiempo y lugar les queda para hacerlo en cl discurso de la obra.

Nosotros mismos somos testigos de ello (cjemplos, más adelante). Y cuando don Quijote quiere disuadir de su pelea a los del rebuzno, declara:

Los varones prudentes, las repúblicas bien concertadas, por cuatro cosas han de tomar las armas y desenvainar la cspada y poner a riesgo sus personas, vida y haciendas: la primera, por defender la Fe católica... ${ }^{2}$

Más de dos docenas de pasajes equivalentes se pueden citar, pero solamente tracré a cuento uno más porque ha sido aducido en contra por Hatzfeld. En una de sus conversaciones con Sancho (II, 8), don Quijote responde una y otra vez sin reservas, sin desconcierto y en perfecta armonía de pensamiento y de obra ${ }^{3}$, que de

yo... voy por la angosta senda de la caballería andante, por cuyo cjercicio desprecio la hacienda" (II, 32). Pero así es solamente en la cita perjudicialmente acortada que hace Hatzfeld, pág. 60. En el texto de Cervantes, don Quijote se defiende elocuentemente de la afrentosa reprensión del capellán de los duques, hombre a quien Cervantes pinta con más soberbia que caridad y más mandonería que autoridad: ". . caballero soy y caballero he de morir, si place al Altísimo. Unos [letrados, en oposición al hombre de armas] van por el ancho campo de la ambición soberbia; otros, por el de la adulación servil y baja; otros, por el de la hipocresía engañosa; y algunos por el de la verdadera religión; pero yo, inclinado de mi estrclla, voy por la angosta senda de la caballería andante, por cuyo ejercicio desprecio la hacienda pero no la honra". Don Quijote sigue aquí la imagen ascética del camino fácil ancho y llano del vicio, y el empinado, estrecho y fragoso de la virtud; lo del "ancho campo" se aplica a Jos vicios de la ambición, de la adulación y de la hipocresía, por el que muchos letrados intemperantes se echaban a andar; pero el cuarto miembro de la enumeración no forma scrie $(1,2,3$ y 4), sino que, con su verdadera religión, se opone a los tres primeros como reconfortante excepción: algunos letrados van por el campo de la verdadcra religión, aludiendo a que el letrado allí presente no entraba en esos "algunos". Por lo tanto, lo de "ancho campo" no está pensado para "la verdadera religión". La frasecilla final (suprimida por Hatzfeld), "pero no lo honra", tiene el mismo valor de réplica contundente a la ofensa del intempcrante letrado, y además, con su fórmula de oposición: "desprecio la hacienda, pero no la honra", resume y afirma su descuido de los bienes y placeres nateriales y su solo cuidado y estima de los espirituales, idea no sólo dicha, sino realizada y vivida cn todo el libro, aunque contradicha puntualmente por Hatzfeld en su artículo.

2 II, 27. Y sigue predicándoles la doctrina de "Jesucristo, Dios y hombre verdadero", de tal manera que Sancho, lleno de admiración, dice entre sí: - "El diablo me lleve si este mi amo no es tólogo".

3 Dice Hatzfeld que don Quijote se queda "algo corrido"; pero eso no se ajusta al texto cervantino. 
los caballeros muertos "los gentiles sin duda están en el infierno; los cristianos, si fueron buenos cristianos, o están en el purgatorio o en el cielo"; que resucitar a un muerto es mayor hazaña que matar a un gigante; que la fama de los santos es mejor que la de los héroes de este mundo. Entonces Sancho le propone meterse a frailes, verdadero atajo para llegar al cielo. "Todo eso es así, pero no todos podemos ser frailes, y muchos son los caminos por donde lleva Dios a los suyos al cielo: religión es la caballería; caballeros santos hay en la gloria". "Religión es la caballería", es claro, no significa que sca en sí suficiente y oponible a la religión de Cristo, sino que ejerciendo bien la caballería se sirve también a Dios, y que siendo buen cristiano en la caballería se gana también el cielo. No podemos ver justificación alguna para que se nos presente esta criatura artística como contraria a la Iglesia ni a la España contrarreformista en "tendencia luterana". Santa Teresa decía que entre los pucheros anda el Señor, para significar que haciendo cada uno su menester sirve y adora con eso a Dios. Mateo Alemán lo expresa por boca de su Guzmán (I, I, 4): "Procura ser usufructuario de tu vida, que usando bien della, salvarte puedes en tu estado". Y Guillén de Castro (Las mocedades del Cid, comedia primera, vv. 2165-2194) hace decir a Rodrigo:

El ser cristiano no impide al ser cavallero.

Para general consuelo

de todos, la mano diestra

de Dios mil caminos muestra, y por todos se va al cielo.

Y assí el que fuere guiado

por el mundo peregrino

ha de buscar el camino

que diga con el estado.

Para el bien que se promete

de un alma limpia y sencilla,

lleve el fraile su capilla

y el clérigo su bonete;

y su capote doblado

lleve el tosco labrador,

que quiçá acierta mejor

con el surco de su arado.

$\mathrm{Y}$ el soldado y cavallero,

si lleva buena intención,

con dorada guarnición,

con plumas en el sombrero,

a cavallo y con dorada

espuela, galán divino,

si no es que yerra el camino,

hará bien esta jornada;

porque al cielo caminando,

ya llorando, ya riendo,

van los unos padeciendo

y los otros peleando. 
Para citas bastan. Los hombres más representativos de la España contrarreformista, doctrinales y artistas, explican, predican y representan que, cumpliendo cada hombre los deberes de su estado, está sirviendo a Dios, se entiende que si se acatan las doctrinas de la Iglesia y se cumple con los debcres religiosos. Una exigencia de ascetismo general no la hubo ni la pudo haber, porque habría implicado la supresión de la nación española al acabarse los días de aquella generación. No faltaría alguna alma llameante (de fanatismo, no de caridad) que mirase la variada población de España bipartida en ascetas (hombres de Dios) y no ascetas (bestias del diablo); pero no era esa la doctrina de la Iglesia, ni menos la ley de vida (de inmediata muerte) que regía a la nación española. Y sin embargo, por difícil que sea de creer, esa imposible vara es con la que el Prof. Hatzfeld quiere medir a don Quijote en nombre de la Iglesia y de la España contrarreformista; y como don Quijote no es un asceta, Hatzfeld falla con palabras de Pascal, pero sin su espíritu: "Il veut faire l'ange et fait la bête" (pág. 69).

Tanto mi razón como mi sentido católico se niegan a aceptar tal alternativa. Los valores religiosos son absolutos, los temporales relativos, pero al fin son valores. Hasta los santos de vida más rigurosa, al juzgar las cosas del mundo, y sobre todo a los hombres, han distinguido siempre lo gris de lo negro, y más en una sociedad de cristianos. El asceta huye de todos los bienes y placeres de este mundo como igualmente engañosos, pero no por eso juzga la conducta de todos los demás hombres como igualmente bestial. Siempre acepta que en el mundo hay mejores y peores, y que hasta en las sociedades más descreídas se impone de algún modo la divina distinción entre el bien y el mal. No reclamamos de modo alguno que se juzguen las cosas de tejas abajo con prescindencia de los valores religiosos; pedimos que un celo mal orientado no nos haga juzgar y sopesar las cosas del mundo con prescindencia de las leyes morales del mundo. A Dios lo que es de Dios, y al César lo que es del César. Hatzfeld no será el único que prefiere el asceta San Pedro de Alcántara al caballero don Quijote, pero dudo que haya quien lo acompañe en su sistemática denigración de don Quijote como caballero porque no es un asceta. Hatzfeld dice plantear la cuestión de si nuestro caballero era o no un asceta, para llenar una laguna de los críticos. La misma laguna se puede comprobar en los críticos e historiadores de Hernán Cortés, del Cid o del Conde-Duque; y análoga -de signo inverso- en los de Santa Teresa, que no han tenido en cuenta si representa el ideal caballeresco o el cortesano de su siglo. Quicro decir, con todo respeto, que no es cuestión pertinente. Cualquiera que haya leído una vez el Quijote está en condiciones de contestar: don Quijote en su locura se cree émulo de Amadís y no de San Pcdro de Alcántara. En el campo secular y mundano de la caballería, y no en el penitente de la ascesis, persigue don Quijote un quimérico ideal de perfección, quimérico porque siendo tal perfección caballeresca de existencia puramente literaria, pretendió don Quijote, en su extraviada fantasía, llevarla a la práctica con la serie de descalabros que conocemos. Ideal quimérico y secular, sin duda, pero sustentado en virtudes no sólo naturales, sino cristianas, cuyo sentido cristiano nunca llega a ahogar la fronda disparatada de la imaginación enferma de aquel hombre de bien. 
Por supuesto, no es ésta la opinión de Hatzfeld. Para él, porque no es asceta don Quijote, lejos de ser hombre bueno, como hasta hoy han creído sus lectores, es una suma de flaquezas y de vicios: don Quijote tiene en acción continua los pecados capitales de la ira, de la gula, de la lascivia; es frívolamente curioso, vanidoso, egoísta, cobardísimo. Tal es el rotrato que de don Quijote hace Hatzfeld. Pero yo sigo prefiriendo, y creo que conmigo la unanimidad de los lectores, otro que hace en pocas líneas don Ramón Menéndez Pidal:

Coincidían éstos [los libros de caballerías] con la epopeya, según lo hemos apuntado, en el tipo de perfección caballeresca, y don Quijote va cumpliendo en sí tanto el ideal de ésta como el de aquéllos cuando va afirmándose en su amor por la gloria, en su esfuerzo inquebrantable ante el peligro, en su lealtad ajena a todo desagradecimiento, en no decir mentira así lo asaetaran, en conocer y juzgar el derecho acertadamente, en ayudar a todo necesitado, en defender al ausente, en ser liberal y dadivoso, en ser elocuente $y$ hasta en entender de agüeros y desear quebrantar los que se muestran adversos, según hacían los viejos héroes españoles. Los poemas caballerescos añadían al ideal de la epopeya una perfección más: el ser enamorado; y ante don Quijote surge Dulcinea, porque "el caballero andante sin amores era árbol sin hojas y sin fruto, cuerpo sin alma". Así, de las embrolladas aventuras de los libros de caballerías sacaba el desbarajustado pensamiento de don Quijote un ideal heroico puro, que entroncaba con el de la antigua epopeya4.

Este retrato concuerda en lo esencial con el de Hegel, el de John Gibson Lockhart, el de Ticck, el de Friedrich W. Schelling, el de Paul de Saint Victor, el de Heine, el de Dostoyevski, el de Croce, el de Wordsworth, el de Menéndez y Pelayo, ei de Unamuno, el de Thomas Mann. Todos ellos ven en don Quijote un alma fundamentalmente noble. $\mathrm{Y}$ preferimos todos estos retratos no porque sean más agradables de mirar, sino porque están basados en verdad. Aunque de pintores de temperamento diverso, todos son fieles al modelo; en el del profesor Hatzfeld no reconocemos modelo. Traigamos de árbitro al testigo de mayor excepción, al constante compañero de don Quijote. Cuando el escudero del Caballero del Bosque retrata a su amo como "tonto pero valiente, y más bellaco que tonto y que valiente" (II, 13),

-Eso no es el mío -respondió Sancho-: digo que no tiene nada de bellaco; antes tiene un alma como un cántaro; no sabe hacer mal a nadie, sino bien a todos, ni tiene malicia alguna: un niño le hará entender que es de noche en la mitad del día, y por esta sencillez le quiero como a las telas de mi corazón, y no me amaño a dejarle por más disparates que haga.

Concupiscencia.-Con repulsión hemos visto a la crítica positivista interpretai como histeria las muestras de favor divino de una Santa Teresa, y con mayor repug.

4 Un aspecto de la elaboración del Quijote, en De Cervantes y Lope de Vega, Buenos Aires, 1940, pág. 34 .

5 Menéndez y Pelayo, para encomiar la grandeza moral del ideal cristiano de caballería, tal como lo concibió y expuso el gran asceta y mártir Raimundo Lulio en el Libre del orde de cavaylería, lo parangona con don Quijote: "El caballero ermitaño, que no es otro que Raimundo Lulio mismo, el cual por la descripción que hace de su persona física parece un precursor del ingenioso hidalgo, lo es también por su doctrina noble, generosa, cándidamente optimista y de una pureza moral intachable". Orígenes de la novela, I, 1943, pág. 127. 
nancia las sucias explicaciones psicoanalíticas del lenguaje de amor divino de San Juan de la Cruz. Descontada la profanación, la misma desaprobación nos merece el que se quiera descubrir la concupiscencia de don Quijote en que "en sueños y pensamientos no se le aparece el ángel inaccesible de Dulcinea, sino... la labradora" que Sancho le hizo pasar por Dulcinea ${ }^{6}$. Sólo una vez habían creído ver los ojos mortales de don Quijote a Dulcinea, y era ella una zafia y fea labradora; como la vió la sueña encantada más tarde en la Cueva de Montesinos (II, 23) y recuerda ese sueño después en una noche de insomnio. El pasaje entero ostenta la ridícula credulidad del caballero demente, y también una caritativa impaciencia, con caridad que se viste de amor caballeresco, por librar a Dulcinca de su lamentable situación. No hay la menor complacencia sensual, no hay la menor morosidad pecaminosa en el recuerdo de la labradora; don Quijote la ve en los campos encantados de la Cueva, y lo que vale en ese pasaje son los campos encantados donde ella queda prisionera y de donde tarda en sacarla la remolonería de Sancho. Analizando este capítulo yo no consigo encontrar indicio alguno que justifique la conclusión de Hatzfeld: "El sueño de don Quijote sobre una escena que alguna vez fué realidad, deja ver una faceta muy especial de la verdad del problema de Dulcinea" (pág. 65). La verdad es que tales sueños y asaltos del recuerdo ni son indicio de concupiscencia ni siquiera se oponen a que el que lo sueña sea un asceta. Testigos los Flores Sanctorum y la Legenda Aurea. Sin resistencia alguna estamos de acuerdo con nuestro querido colega en que don Quijote no es un asceta, pero no por falta de castidad, sino porque su admirable castidad está al servicio de un quimérico ideal caballeresco, y no -por lo menos en la forma imaginativa que en los desvaríos de don Quijote adoptacomo obediencia a los Mandamientos y por guardar su cuerpo y su alma limpios para el Señor. Casto es don Quijote con Maritornes, con Altisidora y con las damas barcelonesas, cuando de ellas se cree solicitado, y sus sobresaltos de miedo a perder la honestidad no son - itodo lo contrario! — pérdida de la honestidad. Para Hatzfeld, el tentar don Quijote la camisa de Maritornes es un acto de concupiscencia (págs. 63-64), pero no es buena interpretación: la camisa de harpillera (detalle que Hatzfeld no ha creído de importancia y lo ha suprimido) de Maritornes tiene la misma función que sus muñequeras de vidrio, la misma que sus cabellos como crines y su mal aliento; la misma función que la venta con su ventero y el cuerno del por-

6 Pág. 65. Es sólo exceso de lenguaje el decir que la Dulcinea ideal no se le aparecía a don Quijote en sus pensamientos. Una infidelidad venial hay también en la cita que Hatzfeld hace de II, 60, donde no se trata de un sueño, sino de las memorias de un desvelado, afligido por el encantamiento prolongado de Dulcinea: "Apeáronse de sus bestias amo y mozo, y acomodándose a los troncos de los árboles, Sancho, que había merendado aquel día, se dejó entrar de rondón por las puertas del sueño; pero don Quijote, a quien desvelaban sus imaginaciones mucho más que la hambre, no podía pegar sus ojos, antes iba y venía con el pensamiento por mil géneros de lugares. Ya le parecía hallarse en la cueva de Montesinos, ya ver brincar y subir sobre su pollina a la convertida en labradora Dulcinea, ya que le sonaban en los oídos las palabras del sabio Merlín que le refería las condiciones y diligencias que se habían de hacer y tener en el desencanto de Dulcinea. Desesperábase de ver la flojedad y caridad poca de Sancho, su escudero, pues, a lo que creía, sólo cinco azotes se había dado, número desigual y pequeño para los infinitos que le faltaban; y desto recibió tanta pesadumbre y enojo, que lizo este discurso:" Etc. 
querizo $(\mathrm{I}, 2)$ : la de poner a prueba, con las cosas más ordinarias, pobres y groseras, el poder trasmutador de la fantasía enferma de don Quijote. Así como la venta se le convierte en castillo, el ventero en castellano, el sonar del cuerno del porquero en aviso de algún enano, las dos mozas del partido en refinadas doncellas, así la camisa de harpillera se le figura de finísimo y delgado cendal, las cuentas de vidrio le dan vislumbres de preciosas perlas orientales, las crines de Maritornes le resultan hebras de oro de Arabia, y el olor del aliento, aroma ${ }^{7}$. Todos hacemos citas fragmentarias, y a veces recosidas con puntos suspensivos, por abreviar y recordar sólo lo pertinente; pero este procedimiento ha sido en esta ocasión muy dañoso, porque lo que en Cervantes es una escena paródica de descarriado conocimiento, en la cita de Hatzfeld queda convertido en otra inesperada de concupiscencia. Hasta la palabra tentar cobra en la transcripción de Hatzfeld un significado fuerte, pero, en mi opinión, inadecuado: "la asió fuertemente de una muñeca, y tirándola hacia sí... la hizo sentar sobre la cama; tentóle luego la camisa... y teniéndola bien asida, con voz amorosa... le comenzó a decir: Quisiera hallarme en términos de pagar tamaña merced... pero yago tan molido y quebrantado que, aunque de mi voluntad quisiera satisfacer a la vuestra, fuera imposible...; si esto no hubiera de por medio, no fuera yo tan sandio... que dejara pasar en blanco la venturosa ocasión" (pág. 63-64). Es verdad que don Quijote, encarnando el ideal caballeresco y el caballero ideal, no sólo está enamorado ("de oídas, que no de vistas", como dice el romance), sino que se figura ser el famoso caballero de quien tantas damas se enamoran ${ }^{8}$. Maritornes, Alti-

7 "Tentóle luego la camisa, y, aunque ella era de harpillera, a él le pareció ser de finísimo y delgado cendal. Traía en las muñecas unas cuentas de vidrio, pero a él le dieron vislumbres de preciosas perlas orientales. Los cabellos, que en alguna manera tiraban a crines, él los marcó por hebras de lucidísimo oro de Arabia, cuyo resplandor al del mesmo sol escurecía. Y el aliento, que, sin duda alguna, olía a ensalada fiambre y trasnochada, a él le pareció que arrojaba de su boca un olor suave y aromático; y, finalmente, él la pintó en su imaginación de la misma traza y modo que lo había lé́do en sus libros de la otra princesa que vino a ver al mal ferido caballero, vencida de sus amores, con todos los adornos que aquí van puestos. Y era tanta la ceguedad del pobre hidalgo, que el tacto, ni el aliento, ni otras cosas que traía en sí la buena doncella no le desengañaban, las cuales pudieran hacer vomitar a otro que no fuera arriero; antes le parecía que tenía en sus brazos a la diosa de la hermosura" (I, 16).

8 Aunque por el modo de citar el profesor Hatzfeld, otra vez el texto resulta desfigurado: "además, uno de sus sueños de caballero andante es que se llegue a decir de él: ¿Qué doncella no se le aficionó y se le entregó rendida a todo su talante y voluntad?", I, 45 (pág. 65). La interrogación forma parte de una indignada réplica al cuadrillero que le había llamado "salteador de caminos", por haber dado libertad a los galeotes; la réplica es una enumeración de las prerrogativas y esenciones propias de los caballeros andantes, y que, por ser caballero andante, le alcanzan a él: “-Venid acá, gente soez y mal nacida: ¿saltear de caminos llamáis al dar libertad a los encadenados, soltar los presos, acorrer a los miserables, alzar los caídos, remediar los menesterosos? ;Ah, gente infame, digna por vuestro bajo y vil entendimiento que el cielo no os comunique el valor que se encierra en la caballería andante, ni os dé a entender el pecado e ignorancia en que estáis en no reverenciar la sombra, cuando más la asistencia de cualquier caballero andante!.Venid acá, ladrones en cuadrilla, que no cuadrilleros, salteadores de caminos con licencia de la Santa Hermandad; decidme: ¿Quién fué el ignorante que firmó mandamiento de prisión contra un tal caballero como yo soy? ¿Quién el que ignoró que son esentos de todo judicial fuero los caballeros andantes, y que su ley es su espada, sus fueros sus bríos, sus premáticas su voluntad? ¿Quién fué el mentecato, vuelvo a decir, que no sabe que no hay secutoria de hidalgo con 
sidora, las damas de la casa de don Antonio Moreno - cree el pobre- dan asaltos a su honestidad. Si fuera un asceta, la defensa sería huir, y si materialmente no pudiera, rechazar violentamente a la tentadora como al mismo demonio. Pero don Quijote no es un asceta casto, sino un hidalgo casto que se cree caballero andante, y, fiel a sus ideales de caballería, tiene que salvar a la vez — icosas de loco!, pensará todo asceta- dos principios: el de su honestidad y el de su galantería. Al desairar a sus enamoradas, el caballero andante perfecto tiene que rendirles el tributo debido a su sin igual hermosura y a la merced que le hacen con su amor. Son reglas del juego que don Quijote cumple; pero su honestidad queda siempre intacta. Bien es verdad que su castidad no tiene fundamentos religiosos, por lo menos en sus manifestaciones caballerescas, sino la mera lealtad a la que ha elegido por scñora de sus pensamientos. Asceta, no lo es, pues; pero casto, sí. Esto basta para el propósito de esta nota, pero si se me permite todavía expresar mi opinión en este punto, diré que don Quijote no es que guarde castidad por lealtad a Dulcinea, sino que, temperamento fundamentalmente casto, halla el caballeresco escudo de la lealtad para preservar su honestidad ${ }^{9}$, dentro del quimérico mundo de la caballcría y de sus normas. Lo fundamental en él es la honestidad; lo demás son fantasías superpuestas.

tantas preeminencias ni esenciones como las que adquiere un caballero andante el día que se arma caballero y se entrega al duro ejercicio de la caballería? ¿Qué caballero andante pagó pecho, alcabala, chapín de la reina, moneda forera, portazgo ni barca? ¿Qué sastre le llevó hechura de vestido que le hiciese? ¿Qué castellano le acogió en su castillo que le hiciese pagar el escote? ¿Qué rey no le asentó a su mesa? ¿Qué doncella no se le aficionó y se le entregó rendida, a todo su talante y voluntad? Y, finalmente, ¿qué caballero andante ha habido, hay ni habrá en el mundo, que no tenga bríos para dar él solo cuatrocientos palos a cuatrocientos cuadrilleros que se le pongan delante?" (I, 45). El pasaje es uno de los capitales del libro, porque en él se hace palpable lo desbaratado de una moral y de unas leyes (las de los libros de caballerías) que se ponen en conflicto irreconciliable en cuanto entran en contacto con la moral y las leyes de una moral históricamente constituída. Pero aquí resplandece también la doble, y aún múltiple mirada de Cervantes, la ironía, que da al libro su insondable profundidad: don Quijote replica orgulloso (sí, señor) en defensa de la orden de caballería, y orgulloso de pertenecer a ella, porque está convencido de que es una institución a su manera santa, con sus trabajos constantes y su desinterés al servicio de los desamparados y de lo justo, y porque está convencido de que, a no ser por ignorancia, todo el mundo está también convencido de ello como de cosa incuestionable. Para llevarlo al pináculo del ridículo y de lo absurdo, Cervantes hace a su héroe decir esta perorata delante de don Fernando y los suyos, del ventero y su gente, del cura y el barbero, del oidor y los cuadrilleros, del barbero del yelmo, de don Luis y sus criados, en fin, de todos los estados de la sociedad histórica, en quienes (con la sola excepción del aquijotado Sancho) las evidencias de don Quijote tenían que rebotar como la cosa más fuera de tino. Y sin embargo, en estos momentos de mayor ridículo - como en la aventura de los batanes y en la de Clavileño-, es donde nos educa la profunda simpatía y radical adhesión de Cervantes por su maltratado héroe, gracias a su genial instrumento literario: la ironía aplicada a la ironía. De concupiscencia, ni rastro.

9 En la escena con Maritornes (I, 16), don Quijote aduce otra excusa adicional (la sola que Hatzfeld cita, sin incluir la capital de lealtad, con lo que la adicional adquiere un valor que en el texto no tiene), una excusa que a los lectores hace soltar la carcajada: el que "yago tan molido y quebrantado que, aunque de mi voluntad quisiera satisfacer a la vuestra, fuera imposible". Lo importante es que la voluntad de don Quijote es la de no satisfacer a ninguna dama desenvuelta o enamorada. 
Vanamente curioso.-Don Quijote quiere conocer a Cardenio y saber su historia ${ }^{10}$, etc. Hatzfeld ve en esta curiosidad un carácter antiascético y por lo tanto antirrepresentativo de la España contrarreformista. Nosotros lo entendemos de otro modo: la curiosidad de don Quijote por saber vidas ajenas la comparten todos los personajes del Quijote, y aun los del Persiles, empezando por el mismo Periandro, el antiquijote, en el sentido que interesa a Hartzfeld. La comparte pues toda la España del 1600 tal como se refleja en el arte de Cervantes incluyendo curas, canónigos y frailes; no podemos ver en ello nada contra la Iglesia ni desentonante en aquella España campeona de la Iglesia. Pues aquella curiosidad nada tenía de chismosa ni de vana, sino todo lo contrario: era simpatética, un modo de caridad y de asistencia. $\mathrm{Y}$, aparte este valor moral, era el recurso novelístico normal en Cervantes (y de los demás narradores de su tiempo) para introducir las vidas de sus personajes, en vez de hacerlo, como hoy se suele hacer, en relato directo del omnisciente autor al curioso lectcr.

VANAGLoRia.-Todas sus buenas obras las hace por alcanzar fama (págs. 61-62). A mi entender, don Quijote, que desea y espera para sí la gloria eterna, no la cree incompatible con la buena fama de este mundo. Tampoco la creía Cervantes, ni ninguno de aquellos excelentes católicos españoles. El deseo de honra era general e imperativo; pero la gloria temporal no era para ellos un Ersatz de la eterna. Antes del antropocentrismo del Renacimiento (de ciertos aspectos del Renacimiento), un tan cabal cristiano como Jorge Manrique hace que la Muerte (es decir, el Desengaño en persona) exponga la doctrina de los tres escalones de vida progresiva: la breve corporal, "la otra vida más larga/de la fama gloriosa" y la eterna (coplas 34-36) 11. En el fervor de la reforma católica, un exerasmista y estricto y celosísimo ortodoxo, Pero Mexía, predica una y otra vez que "los manánimos y grandes corazones principalmente cobdician y procuran" la fama, que la fama es "lo principal a que los hombres animosos y honrados tienen fin", que el deseo de fama es el principal motivo entre hombres para los grandes hechos, estímulo luego de nuevas virtudes "para exemplo y aviso del tiempo presente". Y no lo dice como opinión personal sino como verdad universal, de base a la vez natural y santa: "si la buena fama y gloria es tan gran bien, quanto encarece Salomón y alabavan todos los sabios, y si naturalmente todos desean perpetuar su nombre y memoria, dezime ¿qué fuera desto si no fuera por la Historia?" 12 Los mismos jesuítas, entre los que descollaban los más grandes teólogos del Concilio de Trento y también ejemplares ascetas, aceptaban la legitimidad y virtud de la honra mundana (aunque, por ser unos santos,

10 Hatzfeld le acusa de curiosidad antiascética cada vez que aparece la palabra curiosidad: "digo esto... por curiosidad no más, ¿ha hallado en su escritura alguna vez nombrar piñata?”, II, 62 (pág. 66). Pero tal palabra es ahí un acto delicado de cortesía, como se ve completando la cita: "Pero dígame vuestra merced, señor mío, (y no digo esto porque quiero examinar el ingenio de vuestra merced, sino por curiosidad, no más), ¿ha hallado en su escritura alguna vez nombrar piñata?"

11 Cf. Rosemarie Burkart, Leben, Tod und Jenseits bei Manrique und Villon, en L. Spitzer, Rom. Stil- und Literaturstudien, Marburg, 1931, I, págs. 289-291.

12 Historia imperial y cesárea, "Al lector". Es tópico frecuente en la Silva de varia lección (cf. edición de Madrid, 1933-1934, III, págs. 157, 171, etc.). 
no la buscaban para sí mismos) y la explotaron y explotan desde la fundación de sus primeros colegios como fuente de aprovechamiento y de virtud. Así lo dice el padre Rivadeneira en su Vida del P. Ignacio de Loyola, pág. 93a:

Y porque lo que se hace, se hace por puro amor de Dios, y dél se espera el galardón, se buscan con toda diligencia varios modos de despertar y anjmar los estudiantes al estudio, y se usan nuevos ejercicios de letras y nuevas maneras de conferencias y disputas y de premios, que se dan a sus tiempos a los que se aventajan y hacen raya entre los demás; los cuales, y el puntillo de la honra, y la competencia que se pone entre los iguales, y la preeminencia de los asientos y títulos que les dan cuando los merecen, son grande espuela y motivo para incitar e inflamar a los estudiantes y hacerles correr en la carrera de la virtud; porque, así como la pena y afrenta son freno para detener al hombre en el mal, así la honra y el premio dan grandes alientos para cualquier obra virtuosa, y no sin razón dijo el otro que la virtud alabada crece y la gloria es espuela que hace aguijar, y Quintiliano enseña de cuánto provecho sea esto, y más en los niños, que se mueven por el afecto natural que en ellos es poderoso y los señorea, más que no por la razón, que aún está flaca y sin fuerzas; y aunque la ambición y el apetito desordenado de honra en sí es vicio, pero muchas veces (como dice el mismo autor) es medio para alcanzar la virtud ${ }^{13}$.

Tan legítimo en el mundo parece a un asceta el deseo de honra que trae en ello a colación la autoridad de un gentil.

Severo en demasía ha estado también con don Quijote Hatzfeld al reprocharle estar orgulloso de su ascendencia: "Gutierre de Quijada, de cuya alcurnia yo desciendo" (I, 49; Hatzfeld, pág. 61). Bien sabemos que la cuna noble era uno de los motivos obligatorios de la literatura caballeresca, tan chuscamente contraparodiado en la picaresca; y además en la España de antes lo mismo que en la de después del Concilio de Trento, el celo de la buena cuna era tan "natural" que hasta en los ascetas se tenía en cuenta. El padre Rivadeneira dice de San Ignacio: "Iñigo de Loyola, fundador y padre de la Compañía de Jesús, nació de noble linaje, en aquella parte de España que se llama la provincia de Guipúzcoa..." (pág. 13a). Y de San Francisco Javier: "Este padre fué de nación español; nació en el reino de $\mathrm{Na}$ varra, de noble familia..." (pág. 101b). El Dr. Martín de Olave (jesuíta) "de padres ricos y nobles"; el P. Maestro Diego Laínez, sus padres "personas ricas, honradas y cuerdas (Vida del P. Maestro Diego Laínez, en el mismo tomo, 123a y $131 a)$.

Gula.- "Aunque no tan insistentemente como Sancho, habla a cada instante de comida, no obstante sus ascéticos discursos" (pág. 62; siguen 34 citas). Nuestro distinguido colaborador ve en ello prueba de la glotonería de don Quijote; nosotros no. En la Vida del Padre Ignacio de Loyola, libro de intención y espíritu ascéticos, escrito por el padre Pedro de Rivadeneira, uno de sus compañeros, se habla de comida y de preocupación de los fundadores por su comida con frecuencia no menor que lo que toca a don Quijote: véanse las páginas 18b, 21a, 25a,

13 Cito por la edición Bibl. Aut. Esp., vol. LX, página y columna. 
$26 a, 26 b, 28 a, 29 a$ (dos veces), 32b, 33a, 35a, 35b, 43a, 43b, 44b, 56b, 57a, 58a, todas de los dos libros primeros de la Vida, que son los biográficos ${ }^{14}$. Pero es claro que, aunque se "habla a cada instante de comida", los fundadores de la Compañía estaban muy lejos de ser unos glotones. Se habla de comida porque el sustento, como necesidad diaria, es preocupación diaria ${ }^{15}$. Los fundadores de la Compañía de Jesús, con tanto hablar de comida, comían ascéticamente. También don Quijote comía con admirable moderación y templanza, no obstante las treinta y cuatro veces que, según las citas allegadas, se habla de su comida en las mil setenta y seis páginas de una edición sin notas. Ninguna de esas citas dice que comiera sin moderación o con sensualidad; muchas dicen solamente que comía ${ }^{16}$. No hay por qué dudar de que alguna vez tuviera don Quijote complacencia en comer, ya que era hombre; pero su complacencia no era de carácter goloso, sino como la que pueden permitirse alguna vez hasta los grandes ascetas. En Vincenza, por ejemplo, San Ignacio y dos de sus compañeros recogían tan poca limosna "que apenas tornaban a su pobre ermita con tanto pan que les bastase a sustentar la vida, y cuando hallaban un poquito de aceite o de manteca (quc era muy raras veces), lo tenían por muy gran regalo" (44b). El biógrafo lo cuenta para destacar la extrema pobreza de aquella vida; una interpretación de gula en ese "muy gran regalo" sería tan inadecuada como la que Hatzfeld (pág. 62) saca para don Quijote porque después de un día sin comer (antes, al contrario, bien vaciado el estómago por obra del bálsamo de Fierabrás), debilitado y molido por la pedrea de los pastores (aventura de los carneros) y contrariado por la pérdida de las alforjas, rechace la posible comida de yerbas silvestres que le recuerda Sancho, y declare con ambiciones gastronómicas tan modestas como las de San Ignacio y sus dos compañeros de Vincenza: "-Tomaría yo ahora más aína un cuartal de pan o una hogaza y dos cabezas de sardinas arenques que cuantas hierbas describe Dioscórides" (I, 18). Tras largo tiempo sin comer, y más si es con trabajo y fatigas, ei cuerpo reclama reparo para no perecer. Haciendo San Ignacio la vuelta a España "no faltó Dios a su soldado", dice el P. Rivadeneira, pues "estando bien fatigado y q̨uebrantado su cuerpo, un español, de pura lástima, le llevó consigo y le albergó y reparó, dándole de comer" (29a) ${ }^{17}$. En situación fisiológica semejante don Quijote

14 El libro tercero, por tratar casi solamente del crecimiento de la Compañía en casas y colegios, no contiene apenas materia biográfica, y el cuarto poco más. Sin embargo, se vuelve a hablar de crmida en las páginas $79 b$ y $80 b$.

15 Hatzfeld, pág. 62, apunta en contra de don Quijote: "Don Quijote se preocupa de tener proveídas las alforjas de cosas tocantes a la bucólica", II, 7. Lo mismo que el gran asceta San Ignacio: "Llegado Ignacio a la Universidad de París, comenzó a pensar con gran cuidado qué manera habría para que, descuidado y libre de la necesidad que tenía de la sustentación corporal, se pudiese del todo emplear en el estudio de las artes liberales" (pág. 35a; también 25a, 35b, y en varios otros pasajes).

16 "En el castillo de los duques goza sentado a la mesa: en acabando de comer, II, 23; y en cenando, II, 44; estando a la mesa con los duques, II, 52" (pág. 62). Una de las citas de reproche, pág. 63: "Yo, Sancho, nací para vivir muriendo, y tú para morir comiendo... don Quijote comió algo" (II, 59).

17 Poco después hizo otro tanto, con mejores medios, un capitán francés, "el cual, sabiendo de dónde era, aunque no quién era, le acogió y trató y despidió cortésmente, y le mandó dar de comer y hacer buen tratamiento" (ibid.). 
"pidió que le diesen algo de comer, que traía grandísima hambre" (II, 22); y en otra ocasión: "Cualquiera cosa yantaría yo, porque, a lo que entiendo, me haría mucho al caso..." (I, 2). Le han ofrecido de comer, cosa que bien necesita; su moderación se muestra en esa cualquiera cosa que aceptaría. Yo tengo la cortés esperanza de que nuestro distinguido colaborador no insistirá en contar estos y otros pasajes que aduce como documentaciones de que don Quijote, por falta de ascetismo, esté contra el ideal de la Iglesia.

La mayor parte de las acusaciones de gula que nuestro colaborador hace a don Quijote se refieren a actos de hospitalidad: "El hombre que no rechaza algún palomino de añadidura ${ }^{18}$, I, 1, ni un par de pichones ${ }^{19}$, II, 3..." "Come, y bien a gusto, con los pastores, con don Diego Miranda, en las bodas de Camacho, con el Duque y la Duquesa, con las hermosas pastoras, II, 58, con don Antonio Moreno" (pág. 62). Así, pues, o bien honrando un huésped o bien dejándose honrar. Y la hospitalidad es una virtud no sólo pagana, sino cristiana, que aun los monjes y ascetas consienten se ejercite con ellos. En Venecia el P. Ignacio comía de limosna y dormía en la plaza; un senador de vida regalada sintió una noche aviso del cielo, y saliendo en busca del necesitado, "halló echado a Ignacio en la tierra; y entendiendo que era él el que Dios le mandaba buscar, llévale aquella noche a su casa y trátale con mucho regalo y honra. De la cual queriendo huir Ignacio, se fué después a casa de un español que se lo rogó" (26b). También don Quijote se fué de casa de don Diego Miranda y de la de los duques queriendo huir del regalo; sólo que el P. Ignacio lo hizo por motivos ascéticos y don Quijote por su ideal caballeresco de servicio; el uno huye tanto de la honra como del regalo; el otro del regalo y de la ociosidad. Una cosa nos dice aquí el P. Rivadeneira que reclama nuestra atención: que Dios fué quien avisó al senador para que ejercitase en el asceta la hospitalidad. El mismo P. Rivadeneira nos cuenta también cómo yendo a Córdoba el P. Francisco Villanueva con un su compañero a fundar casa de la Compañía, el deán de aquella catedral, don Juan de Córdoba "hombre poderoso y rico", "mandólos buscar y convidar a comer... Venidos, les ruega y les hace fuerza que quieran posar en su casa, y ellos le obedecieron" (107a). Pero para no andar buscando más casos, recordaremos el más ejemplar y concluyente: San Francisco Javier, con su santa austeridad, "no comía más de una vez al día, y por maravilla gustaba cosa de carne ni bebía vino, si no era alguna vez siendo convidado de algún su amigo, porque entonces comía de lo que le ponían delante sin hacer diferencia ninguna” (104b). ¿Don Quijote asceta? No, desde luego; porque le faltó la intención ascética, pero no porque comiera con gula. A don Quijote, que no era un fraile ni un misionero, sino un

18 Como celebración de días festivos en el yantar ordinario, no todavía de don Quijote, sino del hidalgo pobre Alonso Quijana: "una olla de algo más vaca que carnero, salpicón las más noches, duelos y quebrantos los sábados, lantejas los viernes, algún palomino de añadidura los domingos, consumían las tres partes de su hacienda" (I, 1$)$. Esto para tres personas.

19 El pasaje completo dice: "Don Quijote pidió y rogó al bachiller se quedase a hacer penitencia con él. Tuvo el bachiller el envite: quedóse, añadióse a lo ordinario un par de pichones, tratóse en la mesa de caballerías, siguióle el humor Carrasco, acabóse el banquete, durmieron la siesta, volvió Sancho y renovóse la plática pasada". 
caballero andante, no le podemos cargar como pecado de gula el que hiciera honor a la hospitalidad, aceptada también por misioneros y frailes.

Cobardía.-Confieso que me causa confusión tener que defender a don Quijote de esta tremenda acusación que, de confirmarse, lo destruiría completamente y nos haría echarlo al desván de los trastos olvidados. Da desconsuelo ver cómo Hatzfeld rebusca por todos los rincones del libro indicios de la cobardía de don Quijote; hasta le carga las veces que ante cosas peregrinas queda espantado ('asombrado', no 'temeroso': vive Dios que me espanta esta grandeza...). O le reprocha incapacidad para sufrir dolores (págs. 66-67): "Cuando en el castillo de los duques le salta un gato al rostro y lo araña, por dolor... don Quijote comenzó a dar los mayores gritos que pudo, II, 46". He aquí lo sucedido: "Y volviéndose a los gatos [que él toma por encantadores] que andaban por el aposento, les tiró muchas cuchilladas; ellos acudieron a la reja, y por allí se salieron, aunque uno, viéndose tan acosado de las cuchilladas de don Quijote, le saltó al rostro y le asió de las narices con las uñas y los dientes, por cuyo dolor don Quijote comenzó a dar los mayores gritos que pudo". No nos es posible aprobar la aducción de este pasaje como testimonio de que don Quijote fuera un cobarde o de escaso aguante para el sufrimiento corporal ${ }^{20}$, ni de que no fuera asceta (en lo que sin más pruebas testificales todos convenimos), ni menos de que estuviera contra el ideal de la Iglesia. Puesto en tal trance gritaría cuanto pudiera el más austero asceta, gritarían también Aquiles, el Cid y Juana de Arco. Las demás pruebas no son mejores. $\mathrm{Y}$ aunque lo fueran, no nos parece que el demostrar la falta de valor de don Quijote vendría al propósito declarado, que es el de examinar el ascetismo de don Quijote, pues se puede ser gran asceta y ser atacado cel miedo y aun vencido por él (distinción necesaria). Gran miedo, según el P. Rivadeneira, pasó San Ignacio cuando se vió perdido en los Alpes, miedo que le hizo ir "un gran rato el pecho por tierra, caminando a gatas, más sobre las manos que sobre los pies" (42a). En otro viaje, al atravesar una región en guerra, fué San Ignacio sospechado de espía y, llevado ante el capitán, "cayóle un nuevo miedo, que le hizo dudar si sería bien dejar por entonces aquella su costumbre ${ }^{21}$ y tratar al capitán más cortésmente que solía a los otros. Y la causa desta duda era porque por ventura, si así no lo hiciese, daría ocasión al capitán para pensar que no hacía caso dél y para que, enojado por verse menospreciado, le maltratase e hiciese morir a puros tormentos" 22. Una magnífica demostración de la diferencia de ser atacado y ser vencido

20 Véase cómo se continúa el episodio: "entraron con luces y vieron la desigual pelea; acudió el duque a despartirla, y don Quijote dijo a voces: - ¡No me le quite nadie! ¡Déjenme mano a mano con este demonio, con este hechicero, con este encantador; que yo le daré a entender de mí a él quién es don Quijote de la Mancha! Pero el gato, no curándose destas amenazas, gruñía y apretaba; mas, en fin, el duque se le desarraigó y le echó por la reja".

21 San Ignacio, "porque le tuviesen por rústico y hombre simple, y que sabía poco de cortesías, solía tratar groseramente a todos, y no conforme al estilo común de la gente polida y cortesana, y llainar aun a los señores y principales de vos" $(28 b)$.

22 San Ignacio no quiso por eso mudar su tratamiento, sino que salió del paso callando, con los ojos bajos, a toda pregunta. "A sola esta pregunta: ¿Eres espía? respondió: No soy espía. Y esto por parecerle que si no respondía a esta demanda, por ventura le daría justa causa de enojarse con él y atormentarle" (28b y 29a). 
por el miedo nos la da el P. Rivadeneira en otro pasaje. En la Universidad de París se prepara a San Ignacio un castigo corporal, que él no rehuye, aunque se lo aconsejan.

$\mathrm{Y}$ así, luego sin perder punto, vase al Colegio donde le estaba aparejada la ignominia y la cruz. Sintió bien Ignacio que rehusaba su carne la carrera y que perdía el color y temblaba ${ }^{23}$; más él, hablando consigo mismo, decíale así: "Cómo, ¿y contra el aguijón tiráis coces? Pues yo os diré, don Asno, que esta vez habéis de salir letrado; yo os haré que sepáis bailar". Y diciendo estas palabras, da consigo en el Colegio (38b).

El doctor Gobea, su irritado enemigo, se dejó convencer por la santa elocuencia de Ignacio y no hubo castigo; de lo cual, naturalmente, el santo se alegró, y su biógrafo comenta: "Y vióse la fuerza que Dios Nuestro Señor dió a las palabras de Ignacio, y cómo libra a los que esperan en El" (39a). Los compañeros de San Ignacio, que habían quedado en París, "fueron forzados de anticipar su salida huyendo de la turbación y peligro de la guerra" (42b). A uno de los diez compañeros de San Ignacio (el P. Rivadeneira calla el nombre) que vacilaba entre seguir de caballero andante a lo divino o acogerse a la seguridad de una ermita, se le apareció un hombre con una espada, el cual

con gran ceño y enojo arremete al padre, y con la espada desenvainada como estaba da tras él. El padre, temblando y más muerto que vivo, echó a huir; y él a huir y el otro a seguirle, pero de manera que los que presentes estaban veían al que huía y no veían al que le seguía. Al fin de buen rato, el Padre, desmayado con el miedo, y asombrado desta novedad, y quebrantado con lo que había corrido, dió consigo desalentado y sin huelgo en la posada donde estaba Ignacio, el cual, en viéndole, con rostro apacible se volvió a él y nombrándole por su nombre, díjolo: "Fulano ¿así dudáis? Modicae fidei, quare dubitasti?" (45b).

El P. Salmerón y el P. Pascasio fueron enviados por nuncios de su Santidad a Irlanda, donde "trabajaron mucho por sustentar en la antigua y verdadera fe católica aquellos pueblos ignorantes e incultos"; pero

se volvieron a Francia, porque vieron cerradas las puertas a la verdad, y porque supieron que ciertos hombres perdidos trataban de entregarlos a mercaderes ingleses, y venderlos por dinero, que los querían para entregarlos al rey Henrico de Inglaterra, de cuyas manos milagrosamente habían escapado navegando a Irlanda $(57 \mathrm{~b})$.

A petición del rey de Portugal, compañeros de San Ignacio fueron en 1548 a evangelizar el Reino de Manicongo, en África; bautizaron al rey negro y a muchos otros, pero no consiguieron que los neófitos ajustaran sus costumbres al Evangelio.

23 Este pasaje de la vida del gran asceta es muy pertinente, porque Hatzfeld carga a don Quijote, como una de las pruebas de que no era asceta y de que estaba contra el ideal de la Iglesia, el que una vez "se estremeció y encogí́ de hombros y perdió la color del rostro", II, 63 (pág. 67). Fué con ocasión de unas burlas adobadas para el caballero loco: estando en una galera, de repente "abajaron tienda y con grandísimo ruido dejaron caer la entena de alto abajo". 
No les pareció a los nuestros arrojar las preciosas margaritas a tales puercos, de los cuales no se podía ya esperar sino que, volviéndose a ellos, los quisiesen despedazar y destrozar; y así, porque no les fuese mayor condenación a aquellos miserables el volver atrás del bien conocido y muchas veces predicado, se pasaron a otras tierras de la gentilidad a predicar el Evangelio (72a).

San Francisco Javier, tras uno de sus tres naufragios,

estuvo mucho tiempo escondido entre breñas y bosques por huir de las manos de los gentiles y bárbaros, que le buscaban para darle muerte. Otra vez también escapó de la muerte que le tenían los gentiles ya urdida, metido dentro del tronco de un árbol en el campo, donde estuvo toda la noche escon,dido $(104 b)$.

Ni por pienso aduzco estos pasajes para echar sombras sobre las vidas realmente heroicas de aquellos ascetas; sólo lo hago para mostrar que, aunque fuera verdadera "la medrosidad" de don Quijote, su "temor", "su cobardísima actitud del manteamiento", "su actitud cobarde", "su continua ansiedad por su vida", "su gran temor de perder la vida", con todo eso podría ser un asceta ejemplar si cumpliera otras condiciones. Pero es claro que la acusación no está sustentada en verdad. Cuando don Quijote huye de los arcabuces de los rebuznantes, nuestro colaborador tiene, por una vez, causa verdadera para decir que don Quijote ha tenido miedo a morir, y recoge la "excusa" de algún comentador de que, por sus apaleamientos pasados a manos rústicas, "pierde finalmente los ánimos y se hace cauto en exceso". Y Hatzfeld continúa: "eso es, precisamente, lo que no sólo un santo ni un asceta, pero ni siquiera un héroe o un soldado hubieran hecho, y la excusa, llena de terco orgullo, de] propio don Quijote empeora las cosas: - Me he retirado, pero no huído, II, 27" (pág. 68). Ya vemos, con la lectura de un solo y breve libro, cómo no es así: lo mismo hacen santos y ascetas. Y lo mismo hacen soldados heroicos y competentes. He aquí el caso de don Quijote: estando entre los del rebuzno, que eran "más de doscientos hombres, armados de diferentes suertes de armas, como si dijéramos lanzones, ballestas, partesanas, alabardas y picas, y algunos arcabuces y muchas rodelas", Sancho, por hacer una gracia, "pucsta la mano en las narices, comenzó a rebuznar tan reciamente, que todos los cercanos valles retumbaron. Pero uno de los que estaban junto a él, creyendo que hacía burla dellos, alzó un varapalo que en la mano tenía y dióle tal golpe con él, que, sin ser poderoso a otra cosa, dió con Sancho Panza en el suelo. Don Quijote, que vió tan mal parado a Sancho, arremetió al que le había dado, con la lanza sobre mano; pero fueron tantos los que se pusieron en medio, que no fué posible vengarle; antes, viendo que llovía sobre él un nublado de piedras, y que le amenazaban mil encaradas ballestas y no menos cantidad de arcabuces, volvió riendas a Rocinante, y a todo lo que su galope pudo se salió de entre ellos, encomendándose de todo corazón a Dios, que de aquel peligro le librase, temiendo a cada paso no le entrase alguna bala por las espaldas y le saliese al pecho; y a cada punto recogía el aliento, por ver si le faltaba. Pero los del escuadrón se contentaron con verle huir, sin tirarle" (II, 27). Si don Quijote fuera un santo o un asceta, no necesitaría ciertamente excusa ninguna, porque no toca a ellos este tipo de valentías, como nos ha hecho ver el padre Rivadeneira. Siendo hombre de 
armas, tampoco. Que lo diga cualquier héroe laureado de las últimas guerras mundiales. Que lo diga cualquier teórico de la guerra ${ }^{24}$ : dos hombres contra doscientos; uno sólo armado con armas medievales, ellos con armas modernas; entre el caba. llero defensor y su escudero se interponen tantos "que no fué posible vengarle"; el caballero solo está ya rccibiendo el ataque de la turba y, para colmo, ve que se aperciben contra él las armas de fuego. Sólo en estos últimos años, con el estupor y las discusiones de la bomba atómica, podemos hacernos una idea de lo que en el siglo xvi se sentía de las armas de fuego. Y más por un caballero medieval de repente plantado entre tan diabólicas invenciones: "Bien hayan aquellos benditos siglos que carecieron de la espantable furia de aquellos cndemoniados instrumentos de la artillería, a cuyo inventor tengo para mí que en el infierno se le está dando el premio de su diabólica invención, con la cual dió causa que un infame y cobarde brazo quite la vida a un valeroso caballero, y que, sin saber cómo o por dónde, en la mitad del coraje y brío que enciende y anima a los valientes pechos, llega una desmandada bala (disparada de quien quizá huyó y se espantó del resplandor que hizo el fuego al disparar de la maldita máquina), y corta y acaba en un instante los pensamientos y vida de quien la merecía gozar luengos siglos" (I, 38) ${ }^{25}$.

Don Quijote, en la única ocasión de huída, no necesita excusa, sólo comprensión. Cierto que Cervantes, aquí como siempre, con su genial ironía (simpatética, no satírica), ve a la vez el hecho desde varios costados, y cierto también que se complace morosamente en pintarnos el miedo que don Quijote pasa de las armas de fuego; pero justamente cl estallido de risa que con esa morosidad busca y logra Cervantes se debe a que tanto miedo lo pasa un verdadero valiente. Acabada la risa, el mismo Cervantes, ahora con sonrisa francamente simpatética, nos lo impone: "Cuando el valiente huye, la superchería está descubierta, y es de varones prudentes guardarse para mejor ocasión" (párrafo inicial del cap. 28). Todos admitimos que la genialidad artística de Cervantes en su Quijote consiste, más que en otra cosa, en haber creado unas figuras humanas en toda la densidad, complejidad y autenticidad de las personas humanas. No principios encarnados, no abstracciones personificadas,

24 Cervantes mismo lo ha dicho varias veces, por ejemplo, por boca de Sancho, que sc lamenta del exceso de valentía de su señor: "Deso es lo que yo reniego, señor Sansón -dijo a este punto Sancho-; que así acomete mi señor a cien hombres armados como un muchacho goloso a media docena de badeas. ¡Cuerpo del mundo, señor bachiller! Sí, que tiempos hay de acometer, y tiempos de retirar, y no ha de ser todo: ¡Santiago, y cierra España! Y más, que yo he oído decir, y creo que a mi señor mismo, si mal no me acuerdo, que entre los extremos de cobarde y de temerario está el medio de la valentía; y si esto es así, no quiero que huya sin tener para qué, ni que acometa cuando la demasía pide otra cosa" (II, 4).

25 No era medrosidad de don Quijote, sino general abominación y pensamiento que se había hecho tópico. Por ejemplo, Pero Mexía, Silva, I, 8: "Todo esto [las armas] era liviano, a todo vence en crueldad la invención de la pólvora y artillería, la cual dicen que hizo e imaginó un hombre natural de Alemaña, cuyo nombre no se sabe, ni mereció que dél quedase memoria". Rodríguez Marín, en nota a la pág. 163 del tomo III de su edición póstuma, Madrid, 1948, trae algunas otras citas, y, entre ellas, una de Gracián que casi parece eco del discurso de don Quijote: "ya no hay corazón ni valen fuerzas, ni aprovecha la destreza. Un niño derriba a un gigante; una gallina hace tiro a un león, y al más valiente el cobarde..." 
sino personas vivas y autónomas. En la unidad de la persona y en el sesgo de cada vida hallan concordancia actos que, si los embutimos en esquemas abstractos, resultan incoherentes o contradictorios. Las figuras de don Quijote y Sancho son las más densas y complejas, las más contradictorias, si se quiere, por ser las más autónomas y, en fin, las más humanas de estas creaciones; pero en esta complejidad no entra el que don Quijote mezcle cobardía con valor. ¡Cuánto menos el que don Quijote sea un bravucón, pretendido valiente y verdadero cobarde, como lo pinta Hatzfeld! Cervantes lo concibe como un hombre naturalmente valiente, y su valor personal es el que da tan alta dignidad, sinceridad y seriedad a sus disparatados ideales de caballero andante, porque están apoyados en él, sostenidos en él, vividos con él. Sólo una crítica persecutoria puede hallar cobardía hasta en la estupenda hazaña de los leones: "Más que dichoso al ver que los leones no hacen caso de sus bravatas..." (pág. 67). En verdad, mi querido amigo y colaborador, que esta malicia me ha dejado espantado. Puesto que usted lo dice, por supuesto admito que usted lo ve así; pero consienta usted, se lo ruego, en que yo a mi vez exponga mi propia interpretación: don Quijote está siempre dispuesto a luchar dentro de lo que las leyes de la caballería le ordenan y fuera de lo que le prohiben. No debe, por ejemplo, combatir con villanos, aunque le es lícito castigarlos (I, 15) ${ }^{26}$, del mismo modo que advierte a Sancho que no es lícito al escudero echar mano a su espada para defenderlo aunque lo vea en los mayores peligros $(\mathrm{I}, 8)$. Podrá don Quijote ponerse pálido y se le podrán poner los pelos de punta, pero, pálido y erizado, se apresta a la lucha instantáneamente, sin un relámpago de duda. El misterio o la sorpresa repentina son los que pueden causar tales sobresaltos, y sólo un hombre tan naturalmente valiente como nuestro héroe (ya ve usted, mi querido amigo, que yo le quito a héroe las comillas irónicas que usted le pone) podría sobreponerse en tales casos con tan seguro valor. Obra de su loco ideal caballeresco, se dirá. Sí, obra de su ideal, y ahí está el gran secreto de este héroe, cn quien extravíos de la imaginativa producen excelencias morales verdaderas. Su valor está inscrito en su fantástico mundo de caballerías, entre cuyas normas, lcyes e imaginarias circunstancias vive tan plenamente que entra en los más desiguales combates y en los más asombrosos peligros sin que las más veces se lc ocurra siquiera que pueda ser vencido. Sus grandes héroes (literarios) vencían sicmpre, y él se sabe uno de los grandes héroes caballerescos. Así es como arremete a gigantazos tan grandes como molinos; se mete, solo, en la furia de la más descomunal batalla de dos grandes ejércitos para bajar la

26 Hatzfeld no ha creído necesario atender en su crítica a estas quiméricas leyes de caballería; pero, por ser vigentes en la locura de nuestro caballero, regulan su conducta. Tras el molimiento de los yangüeses (y en otras ocasiones), don Quijote declara la ley y su propio escarmiento: "Mas yo me tengo la culpa de todo; que no había de poner mano a la espada contra hombres que no fuesen armados caballeros como yo; y así, creo que en pena de haber pasado las leyes de la caballería, ha permitido el Dios de las batallas que se me diese este castigo. Por lo cual, Sancho Panza, conviene que estés advertido en esto que ahora te diré, porque importa mucho a la salud de entrambos; y es cue cuando veas que semejante canalla nos hace algún agravio, no aguardes a que yo ponga mano al espada para ellos, porque no lo haré en ninguna manera; sino pon tú mano a tu espada y castígalos muy a tu sabor; que si en su ayuda y defensa acudieren caballeros, yo te sabré defender, y ofendellos con todo mi poder" (II, 15). 
balanza de la victoria por el lado que él defienda; desciende al centro de la tierra; se sube sin pestañear ${ }^{27}$ en un mágico caballo de madera que lo llevará en un santiamén al otro lado del mundo, donde va a vencer a un gigantón, y, para no traer ya a cuento más que la hazaña de valor más asombrosa de todas, quiere acometer en las tınieblas $\mathrm{y}$, viéndose impedido por el momento, aguarda a pie firme durante largas lioras, a un enemigo desconocido, el Misterio en persona, cuyos terribles pasos se oyen en la noche llenando la soledad del bosque ${ }^{28}$. ¿Que todos eran peligros imaginarios? Pero el valor era verdadero. Véase a un hombre delante de un gangster que le amenaza con su pistola, vaya tranquilamente hacia él y con resolución quítesela, y luego que venga un comentarista a llamar a ese hombre cobarde porque resulta después que la pistola del gangster estaba descargada. La aventura de los leones es la que carga de verdad todas las pistolas ficticias del libro. Sancho veía que los gigantes eran molinos, y los ejércitos rebaños; pero Sancho y don Diego y todos los demás acompañantes de don Quijote vieron que los leones eran leones, y huyeron. Para don Quijote sus gigantes eran tan verdaderos como sus leones.

En el espacio que tardó el leonero en abrir la jaula primera estuvo considerando don Quijote si sería bien hacer la batalla antes a pie que a caballo, y, en fin, se determinó de hacerla a pie, temiendo que Rocinante se espantaría con la vista de los leones. Por esto saltó del caballo, arrojó la lanza y embrazó el escudo, y desenvainando la espada, paso ante paso con maravi-

27 "Monta temblando el caballo de madera", dice Hatzfeld (pág. 67); pero el texto de Cervantes no lo autoriza. Don Quijote monta no sólo con valor, sino con alegre galantería. A la Condesa 'Trifaldi, que le pide monte y cumpla su misión liberadora, don Quijote responde: "Eso haré yo, señora condesa Trifaldi, de muy buen grado y de mejor talante, sin ponerme a tomar cojín, ni cal. zarme espuelas, por no detenerme; tanta es la gana que tengo de veros a vos, señora, y a todas estas dueñas rasas y mondas" (II, 41). Durante toda la escena de los preparativos, don Quijote muestra perfecta serenidad, y al subir sobre Clavileño intenta tranquilizar al atemorizado Sancho: "Tapaos, Sancho, y subid, Sancho, que quien de tan lueñes tierras envía por nosotros no será para engañarnos, por la poca gloria que le puede redundar de engañar a quien dél se fía; y puesto que todo sucediese al revés de lo que imagino, la gloria de haber emprendido esta hazaña no la podrá escurecer malicia alguna". Así lo reconoce hasta el Duque-Malambruno, en aquel ornado pergamino que se halló cuando reventaron todos los cohetes que guardaba el vientre de aquel caballo de Troya y que decía: "El ínclito caballero don Quijote de la Mancha feneció y acabó la aventura de la condesa Trifaldi, por otro nombre llamada la dueña Dolorida, y compañía, con sólo intentarla" (ibid.). Pero el profesor Hatzfeld la oscurece, contra la previsión cervantina, tomando pie de que, ya montado y tapados los ojos, se acuerda don Quijote de que también era de madera el caballo de Troya, "y así será bien ver primero lo que Clavileño trae en su estómago" (ibid.). Por estar, en efecto, en el estómago de Clavileño encerrada toda la burla de los cohetes, esta salida de don Quijote es un excelente procedimiento artístico, de cómico suspenso, pues amenaza con hacer fracasar con su descubrimiento aquella broma preparada y quién sabe si todo el programa de burlas de los duques; y por eso (del mismo modo que no permitió que el león se comiera a don Quijote) Cervantes hace que don Quijote desista cuando la Dolorida sale fiadora de la buena fe de Malambruno: "Parecióle a don Quijote que cualquiera cosa que replicase acerca de su seguridad sería poner en detrimento su valentía, y así, sin más altercar, subió sobre Clavileño". Esta es la frase que Hatzfeld copia como testimonio textual ce que don Quijote "monta temblando el caballo de madera".

28 Cervantes pinta de este modo el sentimiento de don Quijote al verse burlado en su deseo de lucha y aventura: "Cuando don Quijote vió lo que era [los batanes], enmudeció y pasmóse de arriba abajo. Miróle Sancho, y vió que tenía la cabeza inclinada sobre el pecho, con muestras de estar 
lloso denuedo y corazón valiente, se fué a poner delante del carro, encomendándose a Dios de todo corazón, y luego a su señora Dulcinea (II, 17).

Después de abierta la jaula, y de desperezarse el león, relamerse y tumbarse dando las nalgas a su desafiante, después de mandar don Quijote al leonero que le diese de palos para irritarlo y echarlo fuera, de pronto se deja nuestro hidalgo convencer del leonero para que dé la aventura por terminada. Se deja convencer porque el leonero, sin saberlo, ha ido a aducirle una de las leyes de sus caballerías ${ }^{29}$. En situación mucho más espantable, en la culminante aventura de los batanes, Sancho ruega y suplica a don Quijote que desista: primero le pide que haga trampas en el juego ("ahora es de noche; aquí no nos ve nadie"); después echa mano de recuerdos de sermones (..."que bien busca el peligro perece en él; así que no es bien tentar a Dios acometicndo tan desaforado hecho; donde no se puede escapar sino por milagro"); luego acude a la lástima, y para llegarle más al corazón a través de la fantasía, se la pide en la fabla contrahecha que usa su señor ("Por un solo Dios, señor mío, que non se me faga tal desaguisado"...) por último Sancho rebaja su petición hasta suplicarle sólo que aguarde hasta el día, que (miente) ya ve cercano. Pero nada puede torcer la voluntad de don Quijote: "que no se ha de decir por mí, ahora ni en ningún tiempo, que lágrimas y ruegos me apartaron de hacer lo que debía a estilo de caballero" (I, 20). Sólo la astucia de Sancho, atando las patas a Rocinante, pudo detener a don Quijote hasta el alba. Ni siquiera su fabla caballeresca pudo conseguir nada, porque no se hizo valer en ella nada realmente caballeresco. Pero el lconero habla otro lenguaje que Sancho:

Ningún bravo peleantc (según a mí se me alcanza) está obligado a más que desafiar a su enemigo y esperarlo en campaña; y si el contrario no acude, en él se queda la infamia, y el esperante gana la corona del vencimiento. -Así es verdad - respondió don Quijote-; cierra, amigo, la puerta, y dame por testimonio en la mejor forma que pudieres lo que aquí me has visto hacer... (II, 17).

Al permitir que el leonero cicrre la jaula, don Quijote no se aparta de "hacer lo que debía a estilo de caballero". No desiste esta vez por lo extraordinario del

corrido" (I, 20). Hatzfeld lo pinta de este otro modo: "No puede sorprendernos el ver que don Quijote se siente feliz cada vez que encuentra excusas, por muy débiles que sean, para escapar del peligro" (pág. 67).

29 La valentía de don Quijote es aquí tan extraordinaria, que Cide-Cervantes tiene que hacer un alto para exclamar: “ Oh fuerte y sobre todo encarecimiento animoso don Quijote de la Mancha, espejo donde se pueden mirar todos los valientes del mundo, segundo y nuevo don Manuel de León, que fué gloria y honra de los españoles caballeros! ¿Con qué palabras contaré esta tan espantosa hazaña, o con qué razones la haré creíble a los siglos venideros, o qué alabanzas habrá que no te convengan y cuadren, aunque sean hipérboles sobre todos los hipérboles? Tú a pie, tú solo, tú intrépido, tú magnánimo, con sola una espada, y no de las del perrillo cortadoras, con un escudo no de muy luciente y limpio acero, estás aguardando y atendiendo los dos más fieros leones que jamás criaron las africanas selvas. Tus mismos hechos sean los que te alaben, valeroso manchego; que yo los dejo aquí en su punto, por faltarme palabras con qué encarecerlos" (II, 17). Como siempre, con humorismo; pero la adhesión cordial de Cervantes para su héroe es innegable. Hatzfeld lo interpreta de este otro modo: "Más que dichoso al ver que los leones no hacen caso de sus bravatas..." (pág. 67). 
peligro, sino por ser ley de caballería. En situación mucho menos grandiosa (aventura de la Carreta de la Muerte) Sancho da en la tecla y le hace desistir también de la batalla:

-Asaz de locura sería intentar tal empresa: considere vuesa merced, señor mío, que para sopa de arroyo y tente bonete, no hay arma defensiva en el mundo, si no es embutirse y encerrarse en una campana de bronce; y también se ha de considerar que es más temeridad que valentía acometer un hombre solo a un ejército donde está la Muerte, y pelean en persona emperadores, y a quien ayudan los buenos y los malos ángeles; y si esta consideración no le mueve a estarse quedo, muévale saber de cierto que entre todos los que allí están, aunque parecen reyes, príncipes y emperadores, no hay ningún caballero andante. - Ahora sí - dijo don Quijote- has dado, Sancho, en el punto que puede y debe mudarme de mi ya determinado intento. Yo no puedo ni debo sacar la espada, como muchas otras veces te he dicho, contra quien no fuere armado caballero. A ti, Sancho, toca, si quieres tomar la venganza del agravio que a tu rucio se le ha hecho; que yo desde aquí te ayudaré con voces y advertimientos saludables (II, 11).

Como en la aventura de los leones, también en la del rebuzno había, pues, razones imperativas dentro de la quimera caballeresca de nuestro héroe; pero en ambas aventuras hay, además, otras dos razones mucho más imperativas, heterogéneas entre sí y que no tienen ya que ver con la conducta de don Quijote: la primera, puramente arquitectural, tiene que ver con la conducta del autor para con su obra: cen la voluntad de escribir una historia imaginaria, que, no lo olvidemos, es la razón germinal de la existencia del Quijote. ¿Iba Cervantes a terminar su segunda parte poco más que comenzada? ¿Para qué, entonces, comenzarla? La segunda razón tiene que ver con la conducta de Cervantes para con su héroe, y alcanza al centro mismo del pensamiento y de la estimativa del poeta, a su responsabilidad por el modo de Weltanschauung creado en la figura de don Quijote, a su actitud entrañable hacia don Quijote: ¿Es que Cervantes iba a consentir que el leonero diese de palos al león, y que el león saltara a tierra y se comiera a don Quijote, o que don Quijote acabara repentinamente sus andanzas, hecho criba por las balas de los rebuznantes? Cervantes, genio de la ironía simpatética, con aquella mirada multilateral con que contemplaba las cosas y las acciones de los hombres, sin duda que no aceptaba para sí como bueno cuanto don Quijote hacía y decía, y más siendo don Quijote una figura paródica; pero si, como dice Mr. Parker y Hatzfeld recoge, Cervantes tenía por su héroe una mezcla de compasión (¡no, no; amor!) y reproche, su reproche nunca fué aversión, y no habría consentido jamás en echar a don Quijote a los leones. ¡Qué absurdo desenlace! ¿Qué contrasentido imposible! No; don Quijote de la Mancha, el de Cervantes, aquel don Quijote sobrio, casto, ingenioso, esforzado y socorredor al servicio del orden moral y de la justicia, cortés, enamorado platónico, valiente y anheloso de perfección, aunque su ideal de perfección estuviera dentro de un mundo quimérico de literatura, no merecía ser destruído entre las garras de los leones ni agujereado por las balas de los rebuznantes. Concedemos sin esfuerzo que sí lo habría merecido este otro recién fraguado don Quijote de Hatzfeld, glotón, concupiscente, irascible sin límites, embustero, cobardísimo, bravucón, egoísta, orgulloso, entrome- 
tido, vanaglorioso, en fin, el que con palabras de Pascal que Hatzfeld acomoda, "veut faire l'ange et fait la bête" (pág. 69).

Uno se pregunta por qué de entre todos los héroes literarios, ha ido Hatzfeld a exigir ascetismo precisamente a don Quijote. Ni el libro ni el título pueden llamar a engaño: $E l$ ingenioso hidalgo, dice el título de la primera parte; El ingenioso caballero, dice el de la segunda; por ninguna parte "el riguroso asceta". Si uno busca ejemplos de ascetismo, su lugar está en las vidas de los santos, en los Flores Sanctorum y en la Legenda Aurea; en la literatura de imaginación, nuestro teatro clásico ofrece sus numerosas comedias de santos. Lícito sería también estudiar por ejemplo si es de buena ley el ascetismo literario del Condenado por desconfiado o el del Saint Antoine de Flaubert, o el predicado por Mateo Alemán entre los escarmientos de su pícaro. Pero nadie, tampoco Hatzfeld, estudia el ascetismo de Miguel Ángel, de Galileo, del Gran Capitán ni del Cardenal Richelieu; nadie el de Hamlet, Britannicus, Gudrun, Werther ni Segismundo. Nuestro colaborador, a pesar de afirmar que "para cualquier español del siglo de oro, el ascetismo religioso representa el más alto nivel de moralidad" (pág. 69), tampoco somete a este extraño examen de ascetismo a los otros personajes del Quijote, no a los duques, no al cura, ni al capellán, ni al canónigo, no a don Diego Miranda, no a don Fernando, ni a Cardenio, ni al cautivo, ni al oidor. Y sobre todo, no somete a Periandro-Persiles, a pesar de encarnar "una forma de catolicismo superior", opuesta por Hatzfeld a la de don Quijote; no somete al inismo Cervantes, a pesar de presentárnoslo como castigando repetidamente a su héroe por no cumplir con el ascetismo (págs. 69-70). No somete a Lope de Vega, el genio de la conformidad con la España de su tiempo, como lo llama Vossler. No a Mateo Alemán, a Góngora o a Quevedo. Quiero decir que con todos fracasaría el ascetismo como con don Quijote. ¿Por qué, pues, lo exige de don Quijote, un héroe paródico? El que los ilustradores lo pinten flaco y el que Cervantes lo describa "seco y amojamado que no parecía sino hecho de carne momia", II, 1 (pág. 58), no descubre relación con el ascetismo, aunque los ascetas sean flacos y amojamados; la "jactancia ascética" de don Quijote, de que Hatzfeld habla (pág. 59), no se comprueba en el libro. No hay cuestión: don Quijote no es asceta; tampoco es otras muchas cosas, por ejemplo, estratega o científico, aunque sea hombre de armas o de conocimientos. Mayor disentimiento nos merecen aún los métodos que Hatzfeld aplica para examinar el ascetismo de don Quijote: con ello resultarían sin ascetismo, no sólo "cualquier español del siglo de oro", desde Felipe II a Lope de Vega, no sólo las demás criaturas de imaginación de Cervantes, incluyendo a Periandro, sino que faltaría el ascetismo, como hemos visto detalladamente, en los verdaderos ascetas y santos. Por último, es asombro y dolor lo que nos causa ver a nuestro sabio cola. borador, con el pretexto ocioso de probar el no ascetismo de don Quijote, empeñado en mostrarnos un don Quijote con todos los vicios contrarios a las virtudes que le son constitutivas. Y lo ha hecho, en parte, aduciendo actos y hechos que no veo comprobados en el libro, y en parte aplicando interpretaciones inadecuadas. Si don Quijote fuera un señor de existencia histórica, por muy bien que yo lo conociera y por mucho que lo hubiera tratado, todavía tendría que admitir la posibilidad de que, 
en momentos desconocidos por mí, el tal señor hubiera cometido actos de gula, concupiscencia, mentira o cobardía. Pero gracias a su naturaleza puramente literaria, don Quijote no ha hecho ni dicho en toda su vida inmortal absolutamente nada más de lo que ha hecho y dicho delante de mí, y, por suerte para su historia verídica y para su crítica justa, lo puede volver a hacer y decir delante de mí y de millones de testigos cuantas veces lo deseemos, sin variar lo más mínimo lo una vez hecho y dicho, lo pensado y lo sentido. $\mathrm{Y}$ siempre comprobamos que los cargos del profesor Hatzfeld carecen de fundamento. Por muy doloroso que nos resulte, tenemos el deber de decirlo, siquiera no sea más que por defender una vez de injusticia a quien siempre estuvo dispuesto a defender a todas las víctimas de la injusticia: Hatzfeld se ha dejado vencer por una aversión hacia la figura de don Quijote ${ }^{30}$. Nunca como aquí, lo mejor ha sido tan enemigo de lo bueno. Lo bueno es la ejemplar entereza moral de don Quijote, universalmente sentida no obstante su locura; lo mejor, la moral de sentido religioso, la única perfecta. Hatzfeld ha visto estas dos morales en competencia y oposición. Pero, a mi juicio, no hay tal oposición, ni confusión tampoco. Es cierto que algunos escritores modernos casi endiosan a don Quijote: Rubén Darío escribe su Letanía a Nuestro Señor Don Quijote, y Fedor Dostoyevski, en busca de modelos de bondad y dignidad máximas para su Príncipe Idiota, encuentra

30 Hasta su estilo lo denuncia: "no hace nada por reprimir sus más peligrosas inclinaciones..., su concupiscencia siempre al acecho"; "La irascibilidad de don Quijote... prácticamente no reconoce límites" (pág. 60); "ni siquiera piensa en refrenar la lengua"; "Así, con una increíble falta de mesura aplica denuestos a todo el mundo"... "no hay en él intención alguna de servir verdaderamente a los demás" (pág. 61). "Rechaza toda culpa o responsabilidad”. “...a cada instante habla de comida..." (pág. 62). "Don Quijote está muy lejos de la continencia (pág. 63). ..."revela su extremada debilidad a las tentaciones..." (pág. 64). "Con la cabeza llena de imágenes sensuales..." (por habcr soñado una vez con la aldeana que Sancho le había hecho pasar por Dulcinea:) "La soñada y encantada deja de ser la ideal Beatriz para hacerse cáda vez más corpórea". "Es siempre el mismo desasiego..." “...ni siquiera intenta cerrar a la tentación el camino de los sentidos". "...vive devorado de curiosidad por niñerías y nonadas" (pág. 65). “...se comporta casi puerilmente con el conductor de las armas" (porque, deseoso de oír la historia prometida, le ayuda a descargar). “...anda siempre quejándose de sufrimientos corporales, vive en continua ansiedad por su vida". "La medrosidad de don Quijote no es menor que su incapacidad para sufrir dolores" (pág. 66). "Más que dichoso al ver que los leones no hacen caso de sus bravatas..." "Las aventuras preparadas por los duques asustan terriblemente a don Quijote". "No puede sorprendernos el ver que don Quijote se siente feliz cada vez que encuentra excusas, por nuy débiles que sean, para escapar del peligro. No ayuda a Sancho cuando lo mantean, eludiendo su deber por mezquinas razones" (pág. 67). "..disfraza su temor frente a su cscudero"... (aventura de la Carreta de la Muerte:) "No queriendo realmente atacarlos, "púsose a pensar de qué modo los acometería con menos peligro de su persona', II, 11". "Así repite su cobardísima actitud del manteamiento". (Al huír de los arcabuces de los rebuznantes:) "...actitud tan cobar. de y egoísta que rebaja a don Quijote a los ojos de Sancho..." "Eso es, precisamente, lo que no sólo un santo ni un asceta, pero ni siquiera un héroe o un soldado hubicran hecho, y la excusa, llena de terco orgullo..." "A veces don Quijote traiciona claramente su oculto egoísmo...", "sc engaña en esto con tanta astucia, que..." "Aquí hasta llega uno a preguntarse si don Quijote no miente a veces con cierta conciencia de que lo hace". (Y en nota, no hallando otra documentación:) "Edmund Gayton, en el siglo xvirr, llamó a don Quijote "cmbustcro descarado'. Cf. E. B. KNowles”, etc. (Y sigue:) "Cide Hamete se siente obligado a debatir este difícil problema" (pág. 68). “...cómo se compadece con la inaudita credulidad del valeroso caballero don Quijote", 1I, 26, según dice irónicamente maese Pedro". "Con palabras de Pascal: Il veut faire l'ange et fait la bête" (pág. 69). 
ante todo a Cristo entre los seres r'cales, y luego a don Quijote, entre las creaciones de la literatura cristiana ${ }^{31}$. Sin tales promiscuidades, ya sabemos a qué sublime ejemplaridad levantó Unamuno la interpretación de nuestro héroe. $\mathrm{Y}$ de varia manera Turgeniev, Tieck, Menéndez Pelayo, Menéndez Pidal, etc. etc., presentan a don Quijote como un cierto ideal de perfección humana. Pero hay perfecciones y perfecciones. Comparado con el programa de santidad al servicio de Dios que se impuso ( ¡y cumplió!) ya en sus cuarenta Teresa de Ávila, el programa de perfección al servicio de su obra y de su propia personalidad a que se sometió un Goethe nos parece bien pobre, y junto a la voluntad de cumplimiento de la una y su alerta permanente, la vida del otro resulta una cadena de claudicaciones, compromisos, flaquezas y distracciones. Si de virtud hablamos, bien sabemos que hay medidas relativas y medidas absolutas. La conducta moral, para la medida absoluta, no alcanza su verdadera y pura calidad de virtud mientras no se santifique con la intención profunda de ejercerla por servicio y amor de Dios. Las virtudes de don Quijote se habrían acendrado y lo habrían convertido de caballero andante en santo, de haber obedecido a una aspiración directamente religiosa en vez de la caballeresca que le obsede. Cierto que don Quijote es una de las personas más nobles y más buenas que la laboriosa imaginación de los hombres ha podido fraguar en la vida entera del arte; pero la perfección religiosa es incomparablemente más alta, las virtudes más acrisoladas y perfectas, cuando trasciende su intención del hombre a Dios. Si de perfección hablamos, eso es lo que a las virtudes de don Quijote les faltó para ser perfectas. Nuestro ilustre colaborador siente apasionadamente esta diferencia; lástima, solamente, que para destacarla haya elegido el camino falso de negar las virtudes seculares de don Quijote. La virtud ascética no necesita que se lcvanten testimonios a don Quijote para hacer valer su incomparable superioridad. Al revés, se podría decir: imaginad más virtudes, si queréis, en un nuevo don Quijote, suponedlas mayores aún, y mientras don Quijote quede apegado a las cosas de este mundo, sus cxcelentes cualidades morales quedarán siempre tan por debajo de la virtud de santidad como lo está la vida temporal de la vida cterna, y el servicio del hombre del servicio de Dios. Con satisfacción encontramos a nuestro colaborador olvidado en una frase de que no ha encontrado en don Quijote más que inmoralidad y flaqueza, y diciendo: "La moralidad de don Quijote está mal orientada, no está sometida a perfecta forma” (pág. 69). Sí; sólo que entendido desde el ideal ascético de la moral, así como el mero ascetismo es insatisfactorio (sólo etapa previa en el camino de perfección) para quien siente el anhclo místico. Quiero decir, pues, que así como se puede ser un asceta sin llegar a místico, así se puede ser un buen cristiano sin llegar a asceta. La Iglesia no ha querido nunca hacer de este mundo un inmenso

- 31 "La idea de la novela [EI Idiota] es presentar un carácter positivamente hermoso. Nada más difícil de hacer... Sólo hay una figura positivamente hermosa, Cristo, y por eso, la aparición de esta personalidad inmensurable, infinitamente maravillosa, es por cierto un milagro incuestionable. ...No haré más que mencionar que, de los personajes hermosos de la literatura cristiana, don Quijote es el más completo". Todavía cita en tercer lugar a Mr. Pickwick, la original imitación de don Quijote. Véase L. B. Turkewich, Cervantes in Russia, en A. Flores y M. J. Benardete, Cervantes across the centuries, New York, 1948, pág. 355. 
cenobio, exigiendo ascetismo de cada cristiano. Tampoco nuestro colaborador, por supuesto, excepto de don Quijote. En ninguna parte reprocha Hatzfeld a Cervantes el no haber escrito una vida de santo en lugar de ponerse a pergeñar una novela paródica de las de caballerías, pero en todo el artículo se siente el reproche a don Quijote de haber enloquecido ${ }^{32}$ con la lectura de los libros de caballerías en vez de haberse convertido, como Ignacio de Loyola, con la lectura de vidas de santos: "Me pesa... que este desengaño ha llegado tan tarde que no me deja tiempo para hacer alguna recompensa leyendo otros que sean luz del alma" (II, 74), cita de don Quijote moribundo; y a continuación comenta: "Esto no es beatería, sino la lógica reorientación de un alma caída en el error de acuerdo con las verdaderas normas cristianas" (pág. 69). Es gran lástima (por el error y por sus consecuencias) el que Hatzfeld haya creído ver en el ideal de perfección de don Quijote un antropocentrismo enemigo del ideal cristiano teocéntrico (pág. 69); no comprobable tampoco ni en el libro ni en la vida de Miguel de Cervantes es la afirmación de que las derrotas de don Quijote sean un castigo que Cervantes impone a su héroe por no practicar una moral ascética, pues no impone análogos castigos a los otros personajes de su libro (de sus libros), ninguno más asceta que don Quijote; ni tampoco se castiga a sí mismo, cuya vida, aunque de hombre bueno, quebrantó el ideal ascético muchísimo más que la de don Quijote, especialmente si se le aplicara el cuestionario de nuestro colaborador (págs. 69-70). Oyendo a Hatzfeld hablar de don Quijote se le creería hablando del Misanthrope o del Tartufe de Molière, con moral racionalista y volteriana justificada sólo en el bien a la sociedad, y desentendida, por principio, de la justificación en Dios: moral antropocéntrica en lugar del ideal cristiano teocéntrico. Pero la bondad de don Quijote no era puramente social, a lo Molière, sino mundanal de base cristiana. Don Quijote siguió siendo durante su locura un cristiano cabal, con cristianismo tan sencillo como firme. Era, fuera de duda, un caballero, no un asceta, y el libro uno de entretenimiento, no de devoción; por eso ni era propio del héroe secular ni de esta clase de libros estar poniendo constantemente en primer término la significación cristiana de cada cosa; pero es cierto que el sentido cristiano aparece en los momentos oportunos, que no son $\operatorname{pocos}^{33}$, y que ni

32 "Si la locura caballeresca de don Quijote fuera inocente, no habría tenido que reconciliarse con Dios, repudiando expresamente sus lecturas y los efectos de éstas: la perturbación provocada por él en su propio espíritu". Pero claro que don Quijote no se arrepiente (!!) de haber estado loco, ni mucho menos de haber sido casto, veraz, templado, valiente, socorredor, etc., como si esas virtudes hubieran sido máscaras que encubrieran los vicios contrarios. Esta novela es paródica de las de caballerías, con crítica artística y no religiosa, y el repudio final era obligatorio artísticamente.

33 Los caballeros andantes, como dice Vivaldo a don Quijote, "cuando se ven en ocasión de acometer una grande y peligrosa aventura, en que se vee manifiesto peligro de perder la vida, nunca en aquel instante de acometella se acuerdan de encomendarse a Dios, como cada cristiano está obligado a hacer en peligros semejantes; antes se encomiendan a sus damas con tanta gana y devoción como si ellas fueran su Dios; cosa que me parece huele algo a gentilidad" (I, 13). Don Quijote replica que el encomendarse a la dama es ley de caballerías, y que no por eso dejan de encomendarse a Dios (se entiende, por ser el libro de caballerías, consigna principalmente lo pertinente a la caballería, así como los de religión atienden a lo religioso). En cuanto a don Quijote, en los tales momentos primero se encomienda a Dios $y$, si acaso, después a Dulcinea como su caballero que es, según lo 
en las palabras de don Quijote ni en sus actos hay nunca oposición al ideal cristiano, ni siquiera la voluntad ocasional de esquivarlo; ni mucho menos, como es la tesis de Hatzfeld (págs. 58-59), la locura de querer suplantar con una moral puramente secular a la moral cristiana. La moral mundanal de don Quijote está confiadamente inscrita, encajada y asentada dentro de la religión cristiana, y su voluntad de servicio al prójimo es un modo de servir a Dios (varias veces declarado: con Vivaldo, I, 13; con Sancho, II, 8; con Roque Guinart, II, 59). Don Quijote contrasta su estado caballeresco con el de los frailes (viejo tópico de debate, característico de la teocéntrica Edad Media), pero en la Ciudad de Dios de nuestro loco sublime las dos misiones se distribuyen y complementan tan necesariamente como en la Edad Media los oradores, los defensores y los servidores de don Juan Manuel:

Quiero decir que los religiosos, con toda paz y sosiego, piden al cielo el bien de la tierra; pero los soldados y caballeros ponemos en ejecución lo que ellos piden, defendiéndola con el valor de nuestros brazos y filos de nuestras espadas (I, 13).

Del refrán español, nada sospechoso de heterodoxia, a Dios rogando y con el mazo dando, al religioso le toca el ruego, al caballero el mazo. "Así que somos ministros de Dios en la tierra, y brazos por quien se ejecuta en ella su justicia" (ibid.) ${ }^{34}$. Hasta parece que Cervantes quiso prevenir a su héroe contra futuras

vemos en las aventuras del encantamiento (I, 47: "rogad a Dios me saque destas prisiones"); de los leones (II, 17: "encomendándose a Dios de todo corazón, y luego a su señora Dulcinea..."); de la cueva de Montesinos (II, 22: "Y luego se hincó de rodillas y hizo una oración en voz baja al cielo, pidiendo a Dios le ayudase y le diese buen suceso en aquella, al parecer, peligrosa y nueva aventura, y en voz alta dijo luego: - $O$ Oh señora de mis acciones y movimientos, clarísima y sin par Dulcinea del Toboso! Si es posible que lleguen a tus oídos las plegarias y rogaciones deste tu venturoso amante, por tu inaudita belleza te ruego las escuches"); en la del rebuzno (II, 27: "encomendándose de todo corazón a Dios que de aquel peligro le librase"); en la del barco encantado (II, 29: “-Ya están atados -replić Sancho, ¿qué hemos de hacer ahora? - ¿Qué? - respondió don Quijote-, santiguarnos y levar ferro"); en el combate con Tosilos (II, 56: "Finalmente, don Quijote, encomendándose de todo corazón a Dios Nuestro Señor y a la señora Dulcinea del Toboso..."); en el que tuvo con el Caballero de la Blanca Luna (II, 64: "el cual, encomendándose al cielo de todo corazón y a su Dulcinea, como tenía de costumbre al comenzar de las batallas que se le ofrecían, tornó...").

34 Lo mismo en II, 8: en su famosa conversación con Sancho, don Quijote estima repetidas veces la excelencia moral de los caballeros por debajo de la de los santos; pero en la Ciudad de Dios no todos tienen que ser frailes (II, 8). Es la idea perfectamente ortodoxa y muchas veces expresada en nuestra literatura clásica, de que hemos hablado arriba, pág. 335. Hatzfeld dice que "don Quijote se atreve hasta a oponer los libros de caballerías, como fuente de virtudes naturales, a las Sagradas Escrituras, como fuente de virtudes cristianas, en la plática con el canónigo de Toledo, quien amonesta a don Quijote: "Lea en la Sacra Escritura... de la cual saldrá enamorado de la virtud, ensenaado en la bondad, mejorado en las costumbres, valiente sin temeridad, osado sin cobardía, y todo esto para honra de Dios", I, 49. Don Quijote responde: "lea estos libros [de caballerías] y verá cómo... le mejoran la condición... De mí sé decir... que soy valiente, comedido, liberal, bien criado, generoso, cortés, atrevido, blando, paciente, sufridor de trabajo, I, 50" (pág. 58-59). Leo el pasaje original y no hallo comprobada la tesis de Hatzfeld. Primero, a la cita del canónigo falta la cabeza y el medio, que aquí son esenciales, porque hablan, no de la Sagrada Escritura en general, sino sólo del Libro de los Jueces como libro de hazañas y entretenimiento, junto a otros de historias: "Y si todavía, llevado 
interpretaciones torcidas: don Quijote sabe perfectamente que el estado religioso es más perfecto que el caballeresco, y de ninguna manera quisiera, no digo oponerlos o suplantar el uno con el otro, pero ni siquiera equipararlos en lo que toca a la perfección, aunque sí en lo que toca a los trabajos: "No quiero yo decir, ni me pasa por el pensamiento, que es tan bueno el estado de caballcro andante como el del encerrado religioso; sólo quiero inferir, por lo que yo padezco, que, sin duda, es más trabajoso y más aporreado, y más hambriento y sediento, miserable, roto y piojoso" (I, 13). Locura es, sin duda, el querer llevar a la práctica una quimera literaria, pero locura que no se quiere salir del servicio de Dios, que nunca está de espaldas a Dios: "Aún espero en Dios y en su bendita Madre, flor y espejo de los caballeros, que presto nos hemos de ver los dos cual deseamos; tú, con tu señor a cuestas; y yo, encima de ti, ejerciendo el oficio para que Dios me echó al mundo" (I, 49). "Caballero soy, y caballero he de morir, si place al Altísimo" (II, 32). El primer consejo que don Quijote da a Sancho gobernador es: "Primeramente, oh hijo, has de temer a Dios; porquc en cl temcrle está la sabiduría y siendo sabio no podrás errar en nada" (II, 42). Puede su locura hacerle creerse un instrumento de Dios, pero no un sustituto: "Pero Dios mirará por su pueblo, y deparará a alguno que, si no tan bravo como los andantes caballeros, a lo menos no les será inferior en el ánimo, y Dios me enticnde, y no digo más" (II, 1). En el encuentro con las imágenes de San Jorge, San Martín, Santiago y San Pablo, don Quijote, después de loarlos uno por uno, reconoce su propio puesto frentc al de los santos con harta cordura y perfecto sentido cristiano:

Por buen agüero he tenido, hermanos, haber visto lo que he visto, porque cstos santos y caballcros profesaron lo que yo profeso, que es el ejercicio de las armas; sino que la diferencia que hay entre mí y ellos es que ellos fueron santos y pelearon a lo divino, y yo soy pecador y peleo a lo humano.

de su natural inclinación, quisicra leer libros de hazañas y de caballerías, lea en la Sacra Escritura el de los Jueces, que allí hallará verdades grandiosas y hechos tan verdaderos como valientes. Un Viriato tuvo Lusitania; un César, Roma; un Aníbal, Cartago; un Alejandro, Grecia; un conde Fennán González, Castilla; un Cid, Valencia; un Gonzalo Fernández, Andalucía; un Diego García de Paredes, Extremaclura; un Garci Pérez de Vargas, Jerez; un Garcilaso, Toledo; un don Manuel de León, Sevilla, cuva lección de sus valcrosos hechos puede entretèner, enseñar, deleitar y admirar a los más altos ingenios que los leyeren. Esta sí será lectura digna del buen entendimiento de vuestra merced, señor don Quijote mío, de la cual saldrá crudito en la historia, enamorado de la virtud, enseñado en la bondad, mejorado en las costumbres, valiente sin temeridad, osado sin cobardía, y todo esto, para lionra de Dios, provecho suyo y fama de la Mancha, do, según he sabido, trae vuestra merced su principio y origen" ( $I, 49$. Pongo en cursiva lo elegido por Hatzfeld para su cita y dejo en redonda el resto; de la cual tiene otro antecedente gramatical que el que Hatzfeld le hace tener, y le cambia el sentido). En segundo lugar, con las palabras citadas por Hatzfeld no "responde" don Quijote a las citadas del canónigo, como que están en capítulos diferentes, 49 y 50, en la última edición de Rodríguez Marín, Madrid, 1948, a trece páginas de distancia (III, 375 y 388), y en la de Schevill y Bonilla, sin notas, a once (II, 363 y 373-374). A las palabras citadas de don Quijote preceden estas otras: "Y vuestra merced créame, y, como otra vcz le he dicho, lea estos libros y verá cómo le destierran la melancolía y le mejoran la condición si acaso la tiene mala. De mí sé decir" etc. No hay, pues, en el texto de Cervantes tal oposición. Se habla sólo de libros de entretenimiento, y como tal aduce cl canónigo el de los Jueces, con la ventaja, compartida por las otras historias, de ser verídico, y con la ventaja sobre todo de ser santo. 
Ellos conquistaron el cielo a fuerza de brazos, porque el cielo padece fuerza, y yo hasta agora no sé lo que conquisto a fuerza de mi trabajos; pero si Dulcinea del Toboso saliese de los que padece, mejorándose mi ventura y adobándoseme el juicio, podría ser que encaminase mis pasos por mejor camino del que llevo (II, 48) ${ }^{35}$.

Aún vuelve luego en el mismo capítulo a la glorificación, bien española, de Santiago Matamoros. La conversación de don Quijote con Roque Guinart, incitándolo a que deje su mala vida y se convierta, es ejemplarmente cristiana (II, 50), y causa dolor ver cómo Hatzfeld, por puro desafecto, la aduce como testimonio contrario.

"Epopeya profundamente cristiana" llama Unamuno al Quijote (Vida, capítulo último). Y no por lo que Cervantes rectifica a su héroe, sino por la sustancia cristiana del héroe. Más lo fucra, ya lo creo, una Vida de San Francisco Javier escrita con el genio literario con que se escribió el Quijote. Porque don Quijote no fué un asceta; fué un caballero en el mundo. Pero como caballero, a pesar de su locura, fué un cristiano ejemplar.

Amado Alonso

Harvard University.

35 Extraño pasaje donde Cervantes parece entrever un don Quijote curado ("adobándoseme el juicio") y casado. Cristianamente, es más seguro el estado del casado que el del amante platónico. 